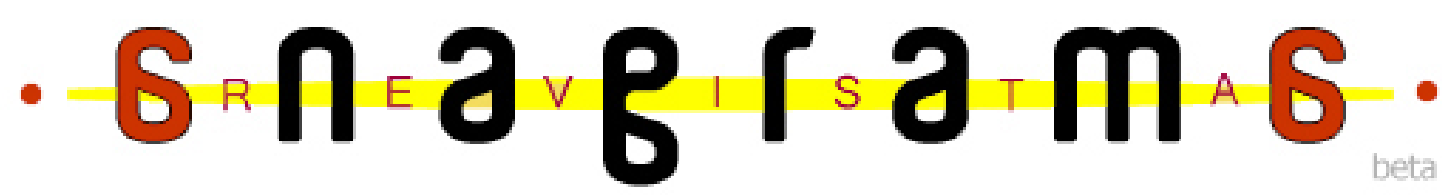

\section{MARKETIIG DIGITAL DA ZOEIRA: A REPRODUÇÃO DOS mETEES Em PEÇAS PUBLICITÁRIAS PARA REDES SOCIAIS}

\section{Gleiciane Rolin de Oliveira'}

\section{Beatriz Silua Goes ${ }^{2}$}

\section{Resumo}

O presente artigo trata das estratégias do marketing digital em forma de zoeira, presentes em posts nas redes sociais. Busca-se analisar o uso de memes em peças publicitárias e as tendências do marketing digital nas redes sociais. Analisou-se os casos do Ovomaltine, envolvendo as marcas McDonald's, Bob's, Burger King, Giraffas e Philips Walita e o caso da Friboi antes e depois da operação carne fraca. Conclui-se que apesar da zoeira, para que os memes se tornem peças-chave para a publicidade é necessário o bom senso e o uso da coerência as estratégias propostas pelo marketing digital no ambiente da internet.

Palauras-chaue: Marketing Digital; Peças Publicitárias; Memes.

\section{IกTRODUÇก̃O}

Atualmente os memes têm sido uma forma bem humorada de interação na internet. Os memes mais populares são de referências políticas, esportivas e econômicas. Em muitos dos casos, os memes viralizam, devido ao seu caráter divertido de fazer uma critica a um assunto factual. Aproveitando que o humor em forma de meme pode levar a mensagem para o receptor de forma engraçada e direta, a publicidade se apropriou dessa forma interativa como estratégia de marketing para atingir os clientes virtuais.

Aplicar as ferramentas do marketing digital em post para as redes sociais é um grande desafio, pois até onde é permitido desenvolver uma peça criativa de forma correta e

\footnotetext{
${ }^{1}$ Graduanda do $7^{\circ}$ período do curso de Publicidade e Propaganda da Faculdade Martha Falcão (DeVry/FMF). E-mail: gleicianne_oliveira@hotmail.com.

2 Orientadora do trabalho. Professora do curso de Jornalismo e Publicidade e Propaganda da Faculdade Martha Falcão (DeVry/FMF). Mestre em Ciências da Comunicação pela UFAM. E-mail: beatriz.goes@fmf.edu.br.
} 
dentro da ética? Como saber o momento certo de desenvolver uma propaganda de oportunidade? Os memes podem influenciar de forma negativava a imagem de uma marca? Não é nada fácil, mas quando se trata da internet, a atenção tem que ser dobrada, devido à possibilidade de interação em que a rede possibilita.

Por conseguinte, esse artigo mostra uma das formas mais coerentes de usar memes em posts para as redes sociais, aproveitando a propaganda de oportunidade, as tendências do marketing digital, o humor como estratégias para conquistar e fidelizar novos clientes e os cuidados que a marca deve ter para não se tornar alvo de memes positivos ou negativos.

\title{
MEME
}

O meme é um tipo de manifestação cultural que tem ganhado destaque na internet. No meio digital, memes podem ser qualquer tipo de assunto ou acontecimentos que estejam em destaques na sociedade, pode ser vídeos, hashtags, fotografias, entre outros. Geralmente os memes são recriados em forma de zoeira, ou seja, feitos com a intenção de se tornar engraçado, afim que vire uma brincadeira ou até mesmo uma piada. $\mathrm{O}$ meme foi conceituado em 1976, proposto pelo biólogo Richard Dawkins em seu livro "O gene egoísta", no qual explicou como batizou seu conceito:

\begin{abstract}
Precisamos de um nome para o novo replicador, um substantivo que transmita a ideia de uma unidade de transmissão cultural, ou uma unidade de imitação. 'Mimeme' provém de uma raiz grega adequada, mas quero um monossílabo que soe um pouco como 'gene'. Espero que meus amigos helenistas me perdoem se eu abreviar mimeme para meme. Se servir como consolo, pode-se, alternativamente, pensar que a palavra está relacionada com 'memória', ou á palavra francês même (DAWKINS, 2001, p. 214).
\end{abstract}

Como exemplo de meme da atualidade que está associado a uma marca, lembra-se do slogan do cantor Compadre Washington: "Sabe de nada inocente", lançado em 2014 pelo Classificado OLX. Desde então tudo que as pessoas acham suspeitas ou diferentes, elas comentam, sabe de nada inocente. O meme, também pode ser um jargão, em 2017 as redes sociais ficaram cheias de "Logo eu", nessa brincadeira participaram celebridades, marcas e internautas. Cada um criava a sua frase, falando de si ou de alguma situação. Por exemplo, "achou que eu não ia descobri, logo eu, Pedro Alvares Cabral”, "quis me jogar no fundo do poço, logo eu, Samara" o Jornalista Evaristo Costa também participou da brincadeira, em seu perfil do Twitter ele Twittou "Quis bater de frente comigo, logo eu Evaristo Costa" e assim cada um tinha a oportunidade de criar sua frase. Um imprevisto pode se tornar meme, assim como aconteceu com o jornalista correspondente internacional 
da BBC que estava fazendo uma transmissão ao vivo, e de repente suas filhas aparecem atrás do vídeo e a mãe aparece abaixada para tira-las. Ai várias pessoas compartilharam nas redes sociais e outras refizeram a cena. Assim como esse, vários slogans, jargões, imprevistos e criticas viralizam rapidamente na internet, e foram transformados em memes. Segundo Bernardo (2012) "Como que o significado de meme se associou à cultura wébica ninguém sabe responder com $100 \%$ de certeza".

\begin{abstract}
Mas, o primeiro resgistro de alguém que usou meme na interwebz foi em 1998. Um cara chamado Joshua Schachter (um dos criadores do del.icio.us) fez um site chamado Memepool, que nada mais era do que um agregador de links virais e coisas legais da internet. Considerado a definição de meme, dá para imaginar que o nome não era por acaso (BERNARDO, 2012).
\end{abstract}

Os memes são reproduzidos na internet em forma de humor, usadas em charges, parodia e em posts para as redes sociais e também como estratégia de Marketing em campanhas publicitárias. O presente artigo tem como missão mostrar alguns exemplos de estratégias, utilizadas pelo Marketing digital para divulgar determinadas marcas, produtos e serviços, através da reprodução dos memes em peças publicitárias para as plataformas digitais.

Quando um meme é transformado em uma peça para a publicidade tem que passar pelo processo de estratégia da mensagem, pois tem que persuadir o público-alvo. Segundo Figueiredo (2005, p. 54) “A persuasão se dá quando localizamos primeiramente os valores do consumidor e depois os associamos ás características do produto que estamos anunciando". Quanto à linguagem de humor:

Fazer rir é uma grande maneira de conquistar antecipadamente a aprovação e a atenção do consumidor. Faça rir, com isso, quebre as barreiras, derrube o muro de proteção que construímos ao nosso redor para nos proteger. Uma peça bemhumorada valoriza a inteligência do consumidor. (FIGUEIREDO, 2005, p.65).

Sabendo como surgiu o meme e o que ele significa dar-se início o uso dessa cultura no ambiente virtual, de forma humorada e atrativa na divulgação de marcas, produtos e serviços.

\title{
MARKETIIG DIGITAL
}

Com o avanço das tecnologias as mídias digitais ganharam grandes destaques na hora de segmentar o mercado, os anunciantes ganharam mais um meio para divulgarem 
suas marcas. Para os autores Alves, Fontoura e Antoniutti (2008:105), "Os computadores estão em todos os lugares e a inclusão digital tem se expandindo numa velocidade maior do que a esperada. Crianças, jovens e adultos estão acessando as redes”. Para Telles:

\begin{abstract}
No marketing digital, a palavras marketing vem antes da palavra digital, ao menos aqui no Brasil. O que quero dizer é que os conceitos fundamentais do marketing, publicidade e design são mais importantes que todas as ferramentas digitais vistas aqui. São as estratégias, o planejamento humano que vão fazer as táticas utilizadas nas ferramentas atuais ou futuras darem resultado. Como em qualquer outra especialidade do marketing, como o marketing esportivo, cultural, político, entre outros, no marketing nas plataformas digitais conceitos como a pirâmide de Maslow, Matriz SWOT, Posicionamento de Jack Trout e AL Ries, os 4 P's de Jeromy McCarthy, Modelo AINDA, os 4 C's de Robert Lauternborn, os 4 A's de Raimar Richers, são bases para um aprofundamento em qualquer especialidade do marketing (TELLES, 2011, p. 176).
\end{abstract}

A interatividade é um dos elementos que a internet proporciona. Quando aplicadas as ferramentas do marketing tradicional no marketing digital elas são complementares, podendo assim trabalhar em parceria proporcionando uma dinâmica virtual e assim captar e fidelizar novos clientes através de um bom planejamento em busca de retorno positivo para a marca, produto ou serviço. A interatividade é um dos elementos que a internet proporciona

\title{
REDES SOCIIIS
}

Muitas pessoas ainda confundem as Redes Sociais com as mídias sociais, mas não é a mesma coisa, mas as redes sociais fazem parte das mídias sócias. Segundo Telles:

Os sites de relacionamento ou redes sociais são ambientes que focam reunir pessoas, os chamados membros, que, uma vez inscritos, podem expor seu perfil com dados como fotos pessoas, textos, mensagens e vídeos, além de interagir com outros membros, criando listas de amigos e comunidades (TELLES, 2011, p. 82).

Novas redes sociais surgem a cada ano, trazendo cada vez mais novas experiências de interatividades, elas têm as opções para as pessoas conhecem novas pessoas e assim iniciar uma nova amizade, as redes sócias também permitem compartilhamentos de conteúdos pessoas e profissionais, permitindo assim a oportunidade de saber o que está acontecendo ao seu redor em tempo real. "A maioria das redes sócias contém o conceito de um grupo - um conjunto de pessoas unidas em um interesse comum" (TELLES, 2011, p. 82). Cada membro de uma rede social faz parte de outros grupos, cada grupo pode ser de diferentes assuntos, mas que faça algum sentido para o associado. 
São considerados redes sociais o Facebook, youtube, WhatsApp, Facebook Messenger, QQ, Instagram, QZone, Tumbrl, Twitter, Sina Weibo, Baidu Tieba, Skype, Viber, Snapchat, Line, Pintrest, yy, Linkedin, Telegram, Vkontate e outros.entre as redes sociais mais populares do mundo, Segundo Drum (2017) "As três primeiras colocadas foram, por ordem de quantidade de usuários, Facebook (1,59 bi), Youtube (1 bi) e WhatsApp (1 bi)".

O Facebook foi criado em outubro de 2003, por Mark Zuckerberg, um estudante de Harvard na época, primeiramente se chamava Facemash, era um site que permitia que os alunos comparassem duas fotografias de identidade para escolherem a mais atrativa. Essa iniciativa fez tanto sucesso, que Zuckerberg juntou mais três amigos para melhorem a ideia, e criaram o Facebook que inicialmente só atendia os alunos e funcionários de Harvard, e depois foi se expandindo para outras universidades e se tornando popular em outros países. Chegou no Brasil em 2008, quando foi traduzido para o português. O youtube foi fundado em fevereiro de 2005, pelos jovens Chad Hurley e Steve Chen em uma garagem em São Francisco (Califórnia, EUA) com o objetivo de compartilhar vídeos com os amigos de forma mais rápida, pois por e-mail era muito mais difícil e lento para carregar esses vídeos. O aplicativo WhatsApp foi criado em 2009 no Vale do Silício, nos Estados Unidos, por dois amigos, ex-funcionários da Yahoo. Através dele as pessoas podem mandar mensagens, áudio, vídeo e fotos. Sobre o Whatsapp ser uma rede social, Drum (2017) afirma que "ele é considerado porque é utilizado no relacionamento das pessoas e possibilita a troca de experiências individuais ou em grupos”.

Existem várias redes sociais e cada uma com o seu diferencial, proporcionando aos seus membros formas diferentes e eficientes de interagir. "Os membros do grupo podem compartilhar notícias e discussões, e os administradores do grupo podem enviar mensagens privadas para qualquer um" (TELLES, 2011, p. 82-83). As principais ferramentas de interação que elas permitem, são as reações de emoções, as curtidas, compartilhamentos, comentários e a linguagem digital. E também a manifestação dos formadores de opinião, que posta suas opiniões e pontos de vistas dos principais assuntos do momento.

\section{MEETES EII POSTS PARA REDES SOCIIIS - CASO MILK-SHAKE OUOMALTIIIE}

Ovomaltine é uma marca de achocolatado que foi criada na Suíça pelo químico Georges Wander em 1904. O produto chegou ao Brasil na década de 1940, chegando aqui, aconteceu um erro nas maquinas, fazendo com que os flocos não dissolvessem como o 
planejado, deixando-o com uma textura mais crocante, foi bem recebido pelos brasileiros, fazendo com que a marca permanecesse com os flocos crocantes até hoje.

Com um início Promitente no Brasil, a Ovomaltine foi esquecida rapidamente. A marca tornou-se popular devido a uma estratégia bem sucedida de Co-Branding ${ }^{3}$, após ser incluído, em 1959, como ingrediente de um dos produtos da rede de lanchonetes Bob's, o milk-shake de Ovomaltine. A parceria com a Bob's foi primordial para fazer com que a marca não desaparecesse no Brasil, fidelizando os consumidores.

No dia 13 de setembro de 2016, a McDonald's anunciou em suas redes sociais que a marca Ovomaltine autorizou a exclusividade da bebida milk-shake (McShake), tirando o licenciamento da marca Ovomaltine da Bob's, que passou a ter o mesmo milk-shake, mas com outro nome "Crocante". Ao portal de notícias G1, o diretor de Marketing da McDonald's Brasil, Branco disse que "Esse era um desejo antigo dos nossos consumidores e encontramos a oportunidade agora para realizar essa parceria". Foi postada nas paginas das redes sociais da McDonald's. No copo do milk-shake (McShake) estava a logo da marca Ovomaltine, confirmando a parceria entre as marcas da rede de hambúrgueres e fastfood McDonald's e o achocolatado Ovomaltine. A figura 1 mostra a divulgação original que casou a guerra de posts meméticos.

Figura 1: McDonald's tira milk-shake de Ovomaltine do Bob's

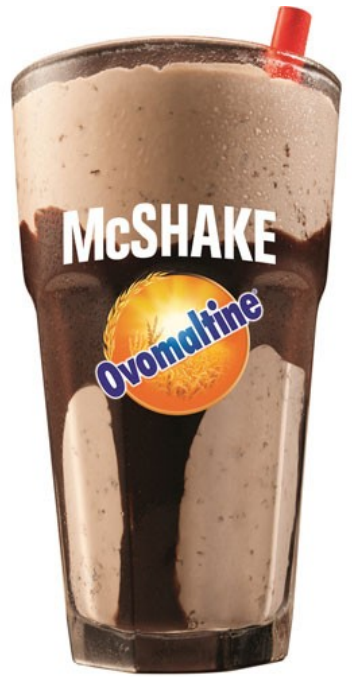

Fonte: G1,2016

${ }^{3}$ Co-branding é uma parceria entre duas ou mais marcas diferentes de produtos e serviços que se unem em uma ação conjunta ou para promover um único produto e serviço. 
No dia seguinte, 14 de setembro, em resposta ao McDonald's, a Bob`s postou no facebook uma imagem dizendo, "Não tem textão, a questão é simples: quem conhece o sabor de verdade não toma \#MilkFake. Para o Jornal O Globo Carlos Pollhuber, diretor de Marketing do Bob's, disse que "a rede usa tecnologias que agilizam a interação com as agências que criam esses conteúdos, para reduzir o tempo de aprovação”. Assim começou os memes Ovomaltine, conforme a figura 2.

Figura 2: Post da Bob's no Facebook

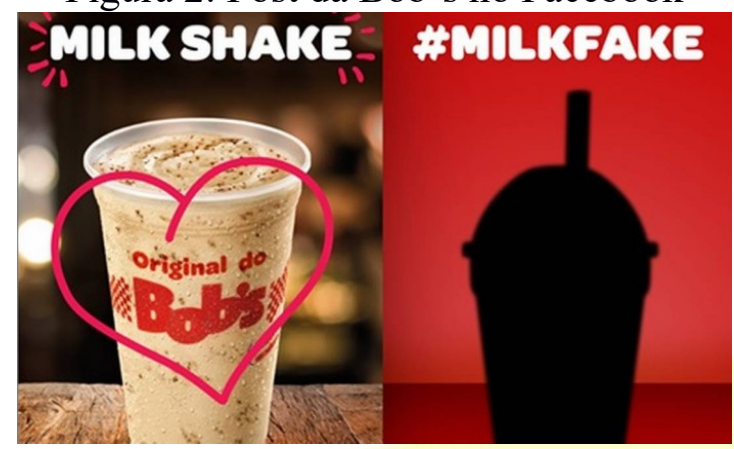

Fonte: BOB'S BRASIL, 2016

Também no dia 14 de setembro aproveitando a oportunidade o Burger King apareceu com um novo meme dizendo: "Calma gente, Shake Crocante com 'aqueleingrediente-que-não-deve-ser-nomeado' aqui também tem". Como mostra a figura 3, que foi postada das redes sociais da Burger King Brasil. Para não ficar para trás, a rede de fastfood brasileira Giraffas também participou dessa guerra dos memes (figura 4).

Figura 3: Post da Burger King no Facebook

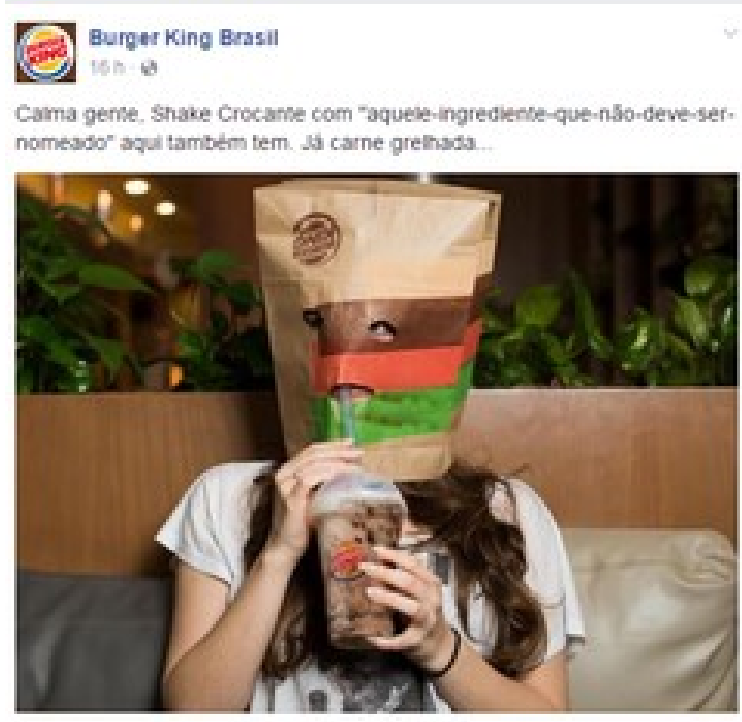

Fonte: ÉPOCA NEGÓCIOS,2016 
Figura 4 : Post do Giraffas no Facebook

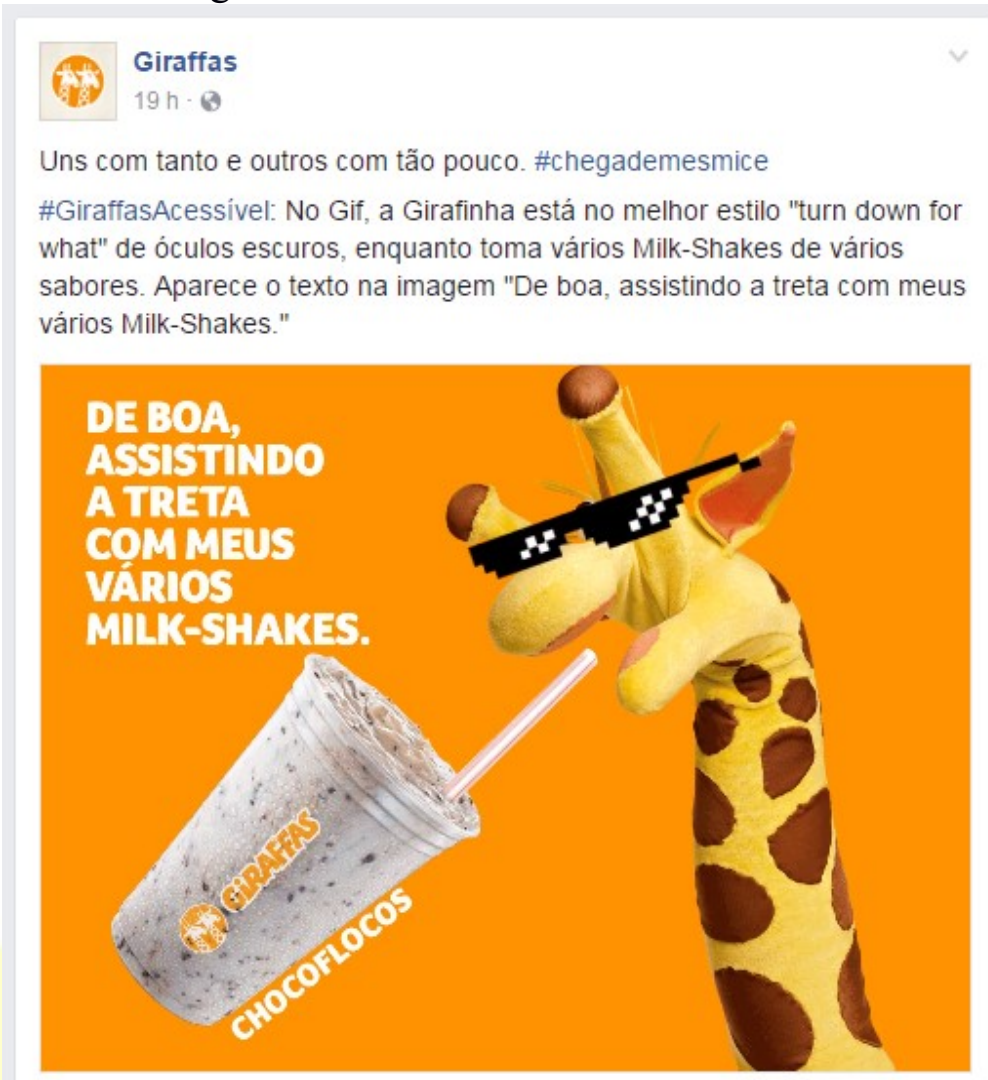

Fonte: ÉPOCA NEGÓCIOS, 2016.

E para terminar essa briga com mais zoeira ainda, a Philips Walita entrou na disputa com um meme genial, sugerindo o uso do liquidificador da marca como forma de as pessoas fazerem seus próprios milk-shakes, sem precisarem sair de casa. Ao jornal $\mathrm{O}$ Globo, a diretora de Marketing da área da saúde pessoal da Philips disse, "Não fazemos humor pelo humor. Só entramos porque nosso lema é: bom é cozinhar em casa"4. Conforme o post na figura 5 .

\footnotetext{
${ }^{4} \mathrm{http}: / /$ epocanegocios.globo.com/Marketing/noticia/2016/09/apos-bobs-e-mcdonalds-burger-king-giraffas-eatephilips-entram-na-briga-do-milk-shake.html
} 
Figura 5: peça publicitaria da Philips Walita no Facebook

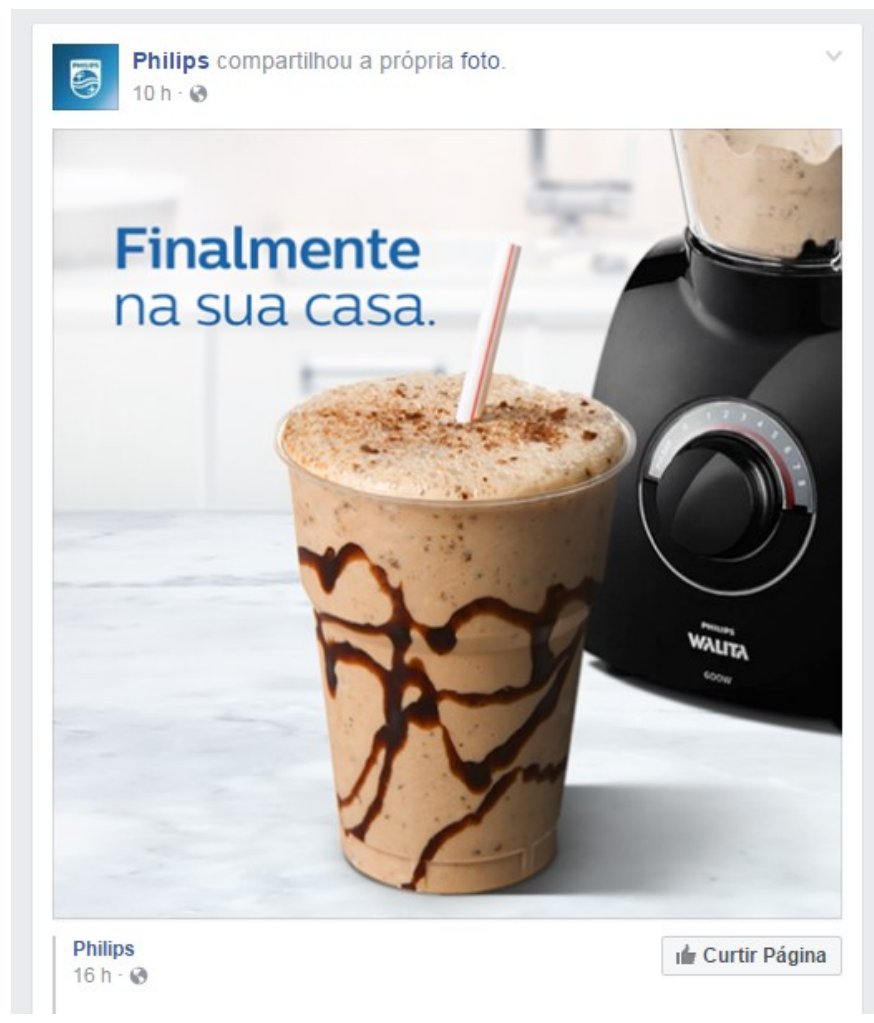

Fonte: ÉPOCA NEGÓCIOS, 2016.

O Jornal O Povo fez um teste as cegas com cinco jornalistas, pegaram o McSheke da McDonald's e o Crocante da Bob's, os dois foram feitos com a marca Ovomaltine, segundo Costa o resultado dessa pesquisa foi:

\footnotetext{
Quatro dos cinco jornalistas conseguiram adivinhar a franquia que preparou o milk-shake mesmo sem a identificação dos copos. A principal diferença apontada por eles foi o sabor mais adoçado da bebida do McDonald's quando comparada com o produto do Bob's (COSTA, 2016).
}

Além dessa pesquisa feita com os jornalistas do Jornal O Povo, acredita-se que muitos brasileiros fãs das marcas envolvidas no caso Ovomaltine, questionaram sobre o sabor já que os ingredientes são os mesmos, Ovomaltine, leite gelado e sorvete de creme. E para preparar é mais fácil ainda, basta colocar três bolas de sorvete de creme $100 \mathrm{ml}$ de leite gelado no liquidificador e bater por um minuto e em seguida acrescentar três colheres de sopa de Ovomaltine. 


\section{QUARDO A MARCA UIRA METE - CASO FRIBOI: MEETES POSITIUDS E REGATIUOS}

A Friboi é uma marca brasileira que atua há mais de 40 anos no mercado de fornecimento de carnes bovinas no Brasil e em mais de 150 países, faz parte do grupo JBS. A marca Friboi afirma em seu site que "com qualidade, simplicidade e trabalho duro, nós oferecemos o melhor da carne para honrar a sua confiança". Desde 2013 o ator Tony Ramos era o principal garoto propaganda da marca e fazia maior sucesso, graças ao slogan da Friboi "carne confiável tem nome”, devido às várias inserções na TV, e a forma de abordagem do Tony Ramos, perguntando para as pessoas em restaurantes e supermercados se a carne que eles estavam adquirindo era Friboi e mostrando também o ambiente da fábrica, com os funcionários da empresa tomando os procedimentos de cuidados com a carne da marca. E foi por isso que os slogans da Friboi foram parar nas redes sociais em forma de meme.

Os memes positivos fizerem com que a marca tomasse um bom posicionamento no mercado, através de seu slogan "carne confiável tem nome”, pois todos os consumidores querem confiar na qualidade de sua comida. E por conta desse slogan também, qualquer carne ou derivados do boi, as pessoas perguntavam se era Friboi. Ou seja, eles gostariam de saber, se a carne era confiável e de qualidade.

Conforme o Portal Click (2013), No Twitter, o efeito é parecido e usuários criaram frases de efeito, tais como: "Desabafando com a carne Friboi, porque ela é confiável", "Vou perguntar para a tia da merenda se a carne é Friboi". Nas redes sociais os memes só ajudavam a popularizar cada vez mais a marca Friboi, como mostra a figura 6 .

Figura 6: Mosaico de memes positivos da Friboi

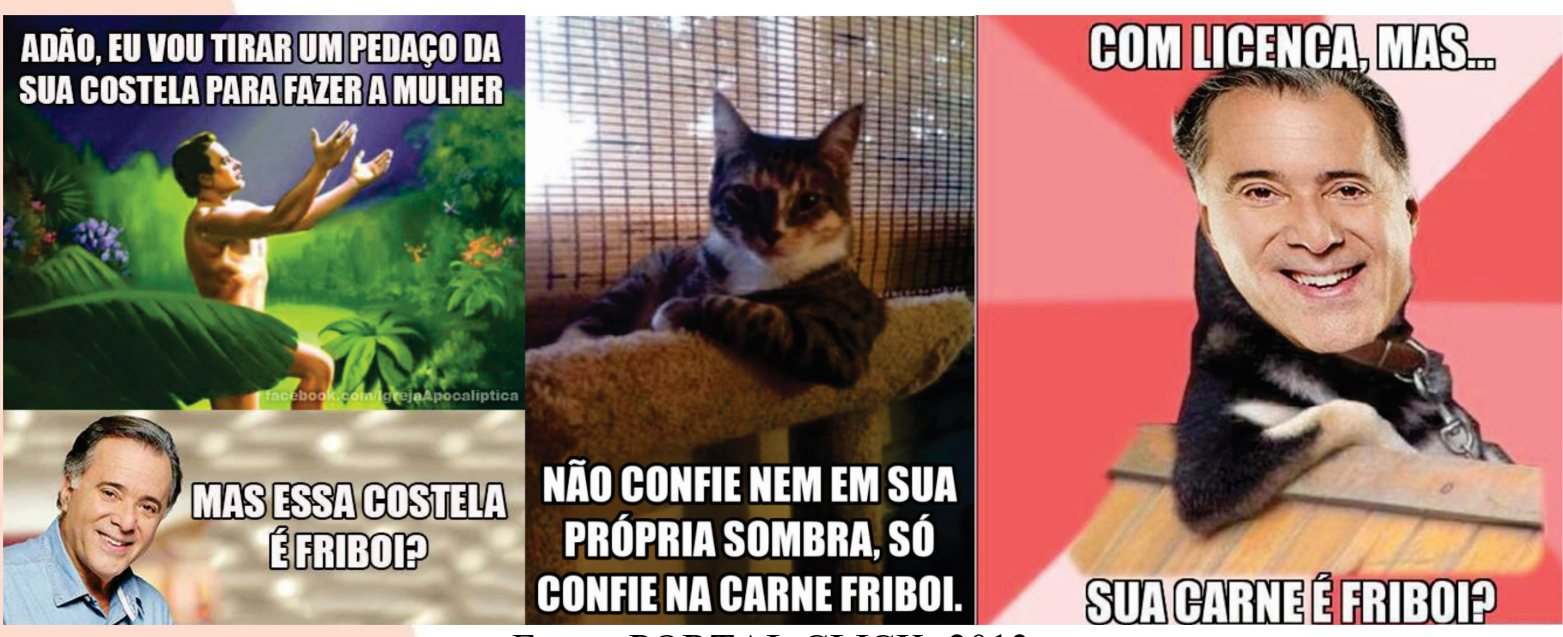

Fonte: PORTAL CLICK, 2013 
Nas redes sociais esse fenômeno é muito comum, as pessoas repetem os slogans das marcas que de alguma forma está chamando a atenção dos consumidores. Sampaio afirma:

\begin{abstract}
Também na propaganda a internet está gerando profundas transformações, principalmente porque permite que a comunicação das marcas ás pessoas se dê de modo cada vez mais individual, fazendo com que o consumidor assuma o controle do processo de comunicação, estabelecendo um diálogo a seu comando (SAMPAIO, 2003, p. 101).
\end{abstract}

Os memes negativos acontecem quando algo dá errado com a marca, produto ou serviço. No dia 17 de março de 2017, a empresa JBS, dona das marcas Seara, Swift, Friboi e Vigor e a BRF dona das marcas Sadia e Perdigão foram acusados de venderem carnes com o prazo de validades adulteradas, pegavam a carnes que já estavam estragadas e mudavam a data de vencimento. Além das carnes estragadas a Operação Carne fraca, também encontrou papelão em algumas carnes.

A figura 7 mostra alguns prints de posts nas redes sociais de memes negativos a respeito da marca Friboi, que foi o tema da matéria, Os memes da Operação Carne Fraca, do Estadão. Os internautas postaram as imagens e fizeram seus comentários de forma humorada, mas também critica, como: "Friboi é Friboi", no churrasco de papelão. "parece que o Luís Augusto não era tão ruim assim, né”, referente a o comercial da sadia que criticava outras marcas, dizendo que ninguém levava de Luís Fernando para casa. "imagem exclusiva do estoque de carnes da Friboi encontrada hoje na operação carne fraca", na imagem cheia de caixas de papelão. "vai um franguinho ai?" no frango de papelão e "Friboi- Qualidade comprovada Hahahahah" na imagem do Tony Ramos. 
Figura 7: Mosaico de memes negativos da Friboi

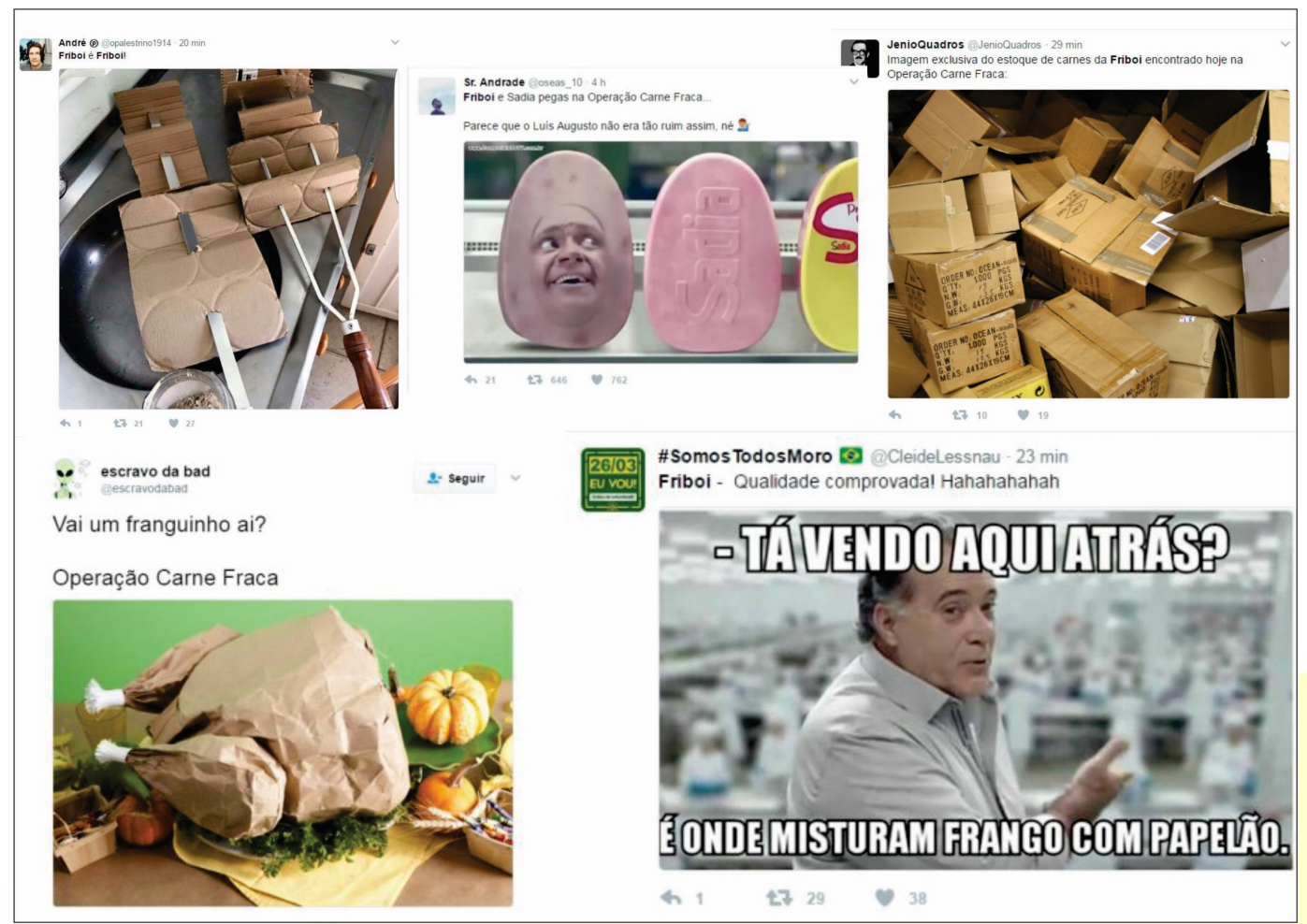

Fonte: ESTADÃO, 2017

A internet mudou o comportamento do consumidor, hoje estão totalmente atentos no que está acontecendo em seu redor, principalmente quando são seguidores de determinadas marcas. "Através da Internet, o consumidor tem mais acesso a informação e por isso consegue conhecer, questionar, comparar e divulgar sua opinião sobre produtos, serviços, marcas e empresas" Cavallini (2008:24). Nos casos memes positivos e negativos mostra o resultado da influencia do consumo na vida dos consumidores. Para Cavallini:

Ao exigir a mudanças, o consumidor torna-se um agente e não mais apenas um target. Gostando ou não, as empresas precisam conviver com esta realidade. Através da internet, o consumidor é capaz de interagir de forma rápida, barata e assíncrona com outros consumidores e com as marcas. O consumidor vai de passeio a ativo, passando a tornar a iniciativa no relacionamento e ter voz ativa. Ele fala mais e é mais ouvido (CAVALLINI, 2008, p. 25).

A comunicação dos consumidores e empresas é mais direta e imediata, podendo assim fazer as possíveis melhores de um serviço, no produto ou até mesmo no próprio atendimento. Cavallini (2008, p.25) afirma que "A interação pode acontecer, nos diversos momentos do ciclo de relacionamento do consumidor com a empresa: atenção, interesse, desejo, compra, pós-compra, fidelização e recomendação". Observa-se que no meme 
positivo, o consumidor teve que passar pelos sete processos de interação citada por Cavallini, à marca Friboi teve que produzir conteúdos para a publicidade, com o intuito de divulgar a marca e torna-la conhecida, no processo de chamar atenção dos consumidores, e investiu em inserções na TV para gerar interesse, criou uma imagem de qualidade para estimular o desejo, usaram Tony Ramos como garoto propaganda para incentivar a compra e quando já estava no pós-compra,fidelizando os clientes e as recomendações estavam sendo feitas, tanto na TV quanto nas redes sócias, através do memes positivos, acontece o escândalo e todo o processo de conquista e fidelização desmorona. Conforme o G1(2017) em apenas um mês depois da operação, "No mercado financeiro, a JBS foi a mais penalizada e perdeu $15,35 \%$ do seu valor, que era $\mathrm{R} \$ 32,6$ bilhões antes da operação e encerrou o ultimo pregão valendo R\$ 27,6 bilhões" 5 .

Para o site do Exame, conforme Dearo (2017), o garoto-propaganda da Friboi, o ator Tony Ramos disse: "Estou surpreso com essa notícia. Eu sou apenas contratado pela empresa de publicidade, não tenho nenhum contato com JBS", afirmou também, "Não sei se faria novamente [comerciais da Friboi], se eles forem inocentados dos erros que estão sendo acusados, eu faria. Eu vou checar essa informação imediatamente" ${ }^{\text {. A }}$ A resposta dele é importante, pois ele estava associado à imagem da marca e foi um dos alvos dos memes negativos.

\section{CONSIDERAÇÔES FInAIS}

Este artigo teve como objetivo analisar as reproduções dos memes em peças publicitárias para as redes sociais, usando como referência dois casos memeticos bastante polêmicos no final do ano de 2016 e inicio de 2017, a do Ovomaltine, envolvendo as marcas McDonald's, Bob's, Burger King, Giraffas e Philips Walita e o caso da Friboi antes e depois da operação carne fraca.

Observou-se no caso Ovomaltine, que a marca que ganhou a guerra dos memes foi o próprio Ovomaltine, pois estava sendo lembrada pelos consumidores todas as vezes que um novo meme surgia falando dos milk-shakes. No caso Friboi a empresa JBS responsável pela marca, depois do escândalo da operação carne fraca, não continuou com os comerciais na televisão. Apenas fez uma nota de esclarecimento pedindo desculpas, mas não fez um

${ }^{5}$ https://g1.globo.com/economia/agronegocios/noticia/um-mes-apos-operacao-carne-fraca-jbs-e-brf-perdem-r5-bi-em-valor-de-mercado.ghtml

${ }^{6} \mathrm{https}$ ://exame.abril.com.br/marketing/friboi-tony-ramos-comerciais-jbs-carne-fraca/ 
reposicionamento da marca, seja criando novos comerciais para a TV ou apresentando um novo garoto propaganda.

Portanto identificou-se que seja de forma positiva ou negativa os memes estão diretamente influenciando no comportamento do consumidor, o humor em peças publicitárias pode causar um grande impacto, direto ou indiretamente para as empresas e faz toda a diferença na hora de um cliente decidir fazer uma compra ou compartilhar suas experiências com outros consumidores.

\section{REFERÊกCIAS BIBLIOGRÁFICAS}

ALVES N. M, FONTOURA, M; ANTONIUTTI C. Mídia e produção audiovisual: uma introdução. Curitiba: Ibpex, 2008.

BERNARDO, K. A origem do termo meme na internet. Disponível em: $<$ http://youpix.virgula.uol.com.br/memepedia/a-origem-do-termo-meme-na-internet/>. Acesso em: 12 Set.2017.

CAVALLINI, R. O marketing depois de amanhã: explorando novas tecnologias para revolucionar a comunicação. São Paulo: Ed. do Autor, 2008.

COSTA, D; BITTENCOURT, A. "Memes: companhias criam campanhas publicitárias no ritmo dos 'trending topics"'. Disponível em: <https://oglobo.globo.com/economia/memescompanhias-criam-campanhas-publicitarias-no-ritmo-dos-trending-topics-20175345>.

Acesso em: 14 Nov. 2017.

COSTA, R. "Ovomaltine. O POVO comparou os milk-shakes de Ovomaltine do McDonald's e do Bob's". O Povo, 2016. Disponível em: $<$ https://www20.opovo.com.br/app/opovo/dom/2016/09/17/noticiasjornaldom,3659506/ov omaltine-o-povo-comparou-os-milk-shakes-de-ovomaltine-do-mcdonald-s.shtml>. Acesso em: 2 Nov. 2017. 
DAWKINS, R. O gene egoísta. São Paulo: Companhia das Letras, 2007.

DEARO, G. "O ator, garoto-propaganda dos famosos comerciais da Friboi, comentou a operação da Polícia Federal”. Revista Exame, 2017. Disponível em: $<$ https://exame.abril.com.br/marketing/friboi-tony-ramos-comerciais-jbs-carne-fraca/>. Acesso em: 14 Nov. 2017.

DRUM, M. As 10 maiores redes sociais - Atualizado. https://www.oficinadanet.com.br/post/16064-quais-sao-as-dez-maiores-redes-sociais Acesso em: 12 Set. 2017.

FIGUEIREDO, Celso. Redação Publicitária: sedução pelas palavras. São Paulo: Pioneiro Thomson Learning, 2005.

MACEDO, F. "Os memes da Operação Carne Fraca”. O Estado de S. Paulo, 2017. Disponível em: <http://politica.estadao.com.br/blogs/fausto-macedo/memes-da-operacaocarne-fraca//>. Acesso em: 14 Nov. 2017..

G1. "Mc Donald's tira milk-shake de Ovomaltine do Bob's". G1, 2016. Disponível em: $<$ http://g1.globo.com/economia/midia-e-marketing/noticia/2016/09/mcdonalds-tira-milkshake-de-ovomaltine-do-bobs.html>. Acesso: 26 Nov. 2017.

"Não tem textão, a questão é simples: quem conhece o sabor de verdade não toma". Bob's Brasil (página do Facebook), 2016. Disponível em: $<$ https://www.facebook.com/bobsbrasil/photos/a.234186663258320.70180.226077797402 540/1270848022925507/?type=3\&theater $>$. Acesso em: 26 Nov. 2017.

OTTONI, L; LÍS, L ; TREVIZAN, T \& G. "Um mês após Operação Carne Fraca, JBS e BRF perdem R\$ 5,5 bi em valor de mercado". G1, 2016. Disponível em: $<$ https://g1.globo.com/economia/agronegocios/noticia/um-mes-apos-operacao-carne-fracajbs-e-brf-perdem-r-5-bi-em-valor-de-mercado.ghtml/> . Acesso em: 14 Nov. 2017. 
SITE PORTAL CLICK. "Comercial da Friboi com Tony Ramos vira meme e é sucesso!".

Portal Click. Disponível em: <http://portalclick.com.br/portalclick/2013/comercial-dafriboi-com-tony-ramos-vira-meme-e-e-sucesso//>.Acesso em: 14 Nov. 2017.

TELLES, A. A revolução das mídias sociais. São Paulo: M.Bookes do Brasil Editora Ltda, 2011. 